\title{
Improving Writing Proficiency, Autonomy, and Critical Thinking Ability through Process-Based Writing Instruction: A Study of Iranian EFL Learners
}

\author{
Afsaneh Bashiri \\ Department of English, Shahreza Branch, Islamic Azad University, Shahreza, Isfahan, Iran \\ E-mail: Bashiri4427@gmail.com \\ Mohsen Shahrokhi (Corresponding author) \\ Department of English, Shahreza Branch, Islamic Azad University, Shahreza, Isfahan, Iran \\ E-mail: shahrokhi1651@yahoo.com
}

Received: 16-07-2015

Accepted: 24-10-2015

Published: 01-01-2016 doi:10.7575/aiac.ijalel.v.5n.1p.232

Advance Access Published: October 2015

URL: http://dx.doi.org/10.7575/aiac.ijalel.v.5n.1p.232

\begin{abstract}
The present study intended to examine the potential role of process-based approach on improving the writing skill, critical thinking ability, and autonomy among Iranian EFL learners. To this end, 60 Iranian intermediate EFL students aged 18-23 were selected from among 120 available Iranian EFL learners. The students were selected based on the result of the Oxford Placement Test (OPT) and further were divided into two groups of control and experimental. Initially, a questionnaire of autonomy was employed by the researchers to retrieve the participants' opinions in the experimental group about the extent to which they considered themselves autonomous. Next, a pre-test for assessing critical thinking ability and a pre-test for assessing writing skill of the participants were administered to both groups. The control group only received the conventional classroom instruction on writing skill which was based on productbased approach, but students in the experimental group students were taught to write using the process-based approach. After 12 weeks of instruction based on process-based approach, the questionnaire of autonomy was again administered to the experimental group; and a post-test for critical thinking and a post-test for writing were administered to the participants in both experimental and control group. The data collected were subject to statistical analysis. The results revealed that process-based approach was of positive effect on learners' writing proficiency, critical thinking ability, and autonomy.
\end{abstract}

Keywords: Process-Based approach, writing ability, critical thinking, learner's autonomy, EFL

\section{Background of the study}

Learning a second language involves the handling of four basic skills; listening, speaking, reading, and writing. In fact, the ultimate skill that learners should master is writing. It is a basic communication skill that cannot be acquired and it can be culturally transmitted or can be learned through formal instruction (Brown, 2001). Writing and speaking, among the four skills of language, are productive skills. Certainly, there are significant differences between them. White (1992) stated that all normal people learn to speak while writing should be taught to them. Compared to speaking, writing requires greater demands on the learners because there is no immediate feedback in written interaction.

As a matter of fact, writing is an enormously complex cognitive activity in which the writer is required to manifest control over a number of variables simultaneously. Control over content, format, sentence structure, vocabulary, punctuation, spelling and letter formation are the variables that are important in the sentence level. In addition, the information must be structured and integrated into cohesive and coherent contexts and discourses by the writer (Bell \& Burnaby, 1984).

The very fact of placing emphasis upon the process has affected the quality of the process of teaching writing. In fact, one of the most important developments in terms of widespread and influential impact on writing instruction until recently is understanding and teaching writing as a process. Almost every current article and book on writing is still concerned with the 'process' in one sense or another and the emphasis in writing instruction saw a general paradigm shift from product to process-oriented between the 1970's and 1980's (Smith, 2000; Applebee, 1986; Faigley et al., 1996). Most of the studies on Process-Based approach aimed at investigating the application of the Process-Based approach and its effects on the students writing achievement. All of the present studied confirm the effectiveness of Process-Based approach on students writing improvement.

In fact, the Process-Based approach emerges as a reaction against the Product-Based approach and is rooted in the 
recognition of the writing process as cyclical, recursive or even disorderly rather than simple and linear. In the Process approach the focus changes from the text to the writer. It gives special emphasis on a cycle of writing activities which move learners from the generating of ideas and the collection of data through to the 'publication' of a finished text (Tribble, 1996). Its nature and the stages through which the learners worked was perhaps the most important feature of process writing approach. This process was not only designed to help student make a better product but it was designed to help them learn to become better writers.

As EFL teachers, we all understand the challenge of writing in a foreign language. We work very hard to improve our learners' writing ability in English but often face an unsatisfactory and even disappointing outcome. This is not surprising because in traditional classes the student will be doing nothing further with their writing and they often pay little attention to the teacher's comments. As Parson (1985) notes, under these conditions, there is not much of a sense of ownership, invention or investment in the writing.

Moreover, because of its emphasis on self-discovery and reflectivity during the writing process the process approach, among many of the approaches to teaching writing, theoretically holds the greatest potential in fostering learner autonomy. In fact, the Process approach originates from writer-based research that highlights the individuals' cognitive processes that happen during the activity of writing (Hyland, 2002). Because of its learner-centered nature it is expected to grant a kind of autonomy to the learner, while peer review and feedback, which is an important component of the process approach as well as a common learner training strategy for learner autonomy, improves its overall potential.

Autonomy has been defined as the ability to take the responsibility of one's own learning (Holec, 1981). Benson (2001) stated that autonomy entails that not only learners attempt to take control of their learning but also they should possess the capacity to do so systematically. Based on the understanding of the writing process and the essence of learner autonomy which is reflectivity, the Process-Based approach which allows for plenty of opportunities for self-reflection through the revision process is expected to have the greatest potential for developing learners' autonomy in writing. The study carried out by Curtis (2001) on student-centered process-oriented peer group approach to writing revealed that it had benefits of the development of learner autonomy and self-confidence as writers in adult ESL learners.

In addition to autonomy that can play a significant role in writing skill, Critical thinking is another variable whose impact on learning in general and on writing skill in particular is a very hotly controversial topic these days. All teachers are now aware of the importance of equipping learners' with critical thinking techniques and they are attempting to teach these techniques in the most appropriate way. In fact, children are not born with critical thinking skills and education could be the first step for promoting critical thinking among them.

Critical thinking is the ability of thinkers to assume responsibility of their own thinking and develop appropriate criteria and standards for analyzing and assessing their own thinking (Elder \& Paul, 1994). There is a consensus, in spite of the range of definitions that have appeared over time, that critical thinking is an active process that goes beyond basic acquisition and memorization of information to the ability to recognize and rationally consider multiple concepts or elements that constitute a body of thought (Adelphi, MD. 2006; Jones, Hoffman, Moore, Ratcliff, Tibbetts, \& Click, 1995).

Developing students' ability to reflect on their own learning process is believed to be helpful for their learning progress. Indeed, higher-order thinking skills increase higher order learning skills which in turn enable students to reach higher levels of language proficiency. Educators of English as a second language (ESL), English as a foreign language (EFL) and modern foreign languages have attempted to integrate the promotion of thinking skills into language curriculum (Renner, 1996).

Since students are moving beyond being simply consumer of knowledge to learning how to make meaningful contributions to that knowledge, it is particularly crucial that they develop strong critical skills. In view of the fact that writing is an activity which forces students to organize their thoughts, think deeply about their topic and present their conclusions in a persuasive manner, writing activities are the best way to teach critical thinking. Goatly (2000) mentioned that the existence of some sort of writing such as persuasive or argumentative writing which have been difficult for the students is one reason that we might expect writing to improve critical thinking.

As a quick review of literature indicates a number of previous studies have been conducted on the impact of ProcessBased approach on writing skill. Moreover, the significance of learners' autonomy and developing the critical-thinking among EFL learners has been highlighted by educators (e.g., Curtis, 2001; Hyland, 2002). However, in an Iranian context, few studies have been conducted on the issues of critical thinking and autonomy development through ProcessBased approach in writing among EFL learners. This study, therefore, is an attempt to investigate the impact of ProcessBased approach on writing skills, autonomy, and critical thinking ability of Iranian EFL students.

\section{Objectives of the study}

As a quick review of literature indicates a number of previous studies have been conducted on the impact of ProcessBased approach on writing skill. Moreover, the significance of learners' autonomy and developing the critical-thinking among EFL learners has been highlighted by educators (e.g., Curtis, 2001; Hyland, 2002). However, in an Iranian context, few studies have been conducted on the issues of critical thinking and autonomy development through ProcessBased approach in writing among EFL learners. This study, therefore, is an attempt to investigate the impact of ProcessBased approach on writing skills, autonomy, and critical thinking ability of Iranian EFL students. 


\subsection{Research Questions}

To achieve the above-mentioned objectives the following research questions were posed as the foci of the current study.

RQ1) To what extent does Iranian EFL students' writing skill improve by applying process-based approach in teaching writing skill?

RQ2) To what extent dose process-based approach in teaching writing skill improve Iranian EFL learners' critical thinking ability?

RQ3) Is there any significant difference between Iranian EFL students' attitudes towards the extent they considered themselves autonomous before and after process-based instruction?

\subsection{Research Hypotheses}

Based on the research questions the following hypotheses were formulated to be sustained or rejected through analysis of the data.

H01) There is no significant difference between control and experimental groups in applying process-based approach for improving Iranian EFL students' writing skill.

H02) There is no significant difference between Iranian EFL students' critical thinking ability taught writing skill through process-based approach and those taught conventionally.

H03) There is no significant difference between Iranian EFL students' attitudes towards the extent they considered themselves autonomous before and after process-based instruction.

A good introduction answers these questions in just a few pages and, by summarizing the relevant arguments and the past evidence, gives the reader a firm sense of What was done and wh y (Beck \& Sales, 2001).

\section{Methodology}

\subsection{Participants}

The study was conducted on sixty Iranian Female intermediate EFL students aged 18-23. They were selected from among 120 available Iranian EFL learners studying at Avaye Mehrvarzan language institute. The students were selected based on the result of the Oxford Placement Test (OPT) and placed into the same level. This group was divided into two groups. The first thirty of the whole sixty students were considered as control group and the second thirty of the whole were considered as experimental group. The sample consisted of only female students to control for the likely effect of gender.

\subsection{Instruments}

The OPT was administered to the participants to ensure they are at the same level of English proficiency and homogeneity is ensured.

Moreover, in order to identify the degree of the students' critical thinking ability, Ennis and Weir's test (1985) was employed. The test aimed at evaluating a person ability to assess an argument and to devise in writing an argument in response. Therefore, it recognizes a creative dimension in critical thinking ability. It was in a form of a letter in which the writer made a proposal and offered a variety of arguments in support of it. Each argument emerged in a separate numbered paragraph. The examinee's task was to read the letter and then write an essay evaluating the argument of each paragraph and the letter as a whole. Also, an argumentative composition test was administered as pretest and posttest to measure the participants' writing ability before and after instructions in both groups. The test's manual included criteria and scoring sheet.

Additionally, the data for the learners' autonomy was retrieved through the Learner Autonomy Questionnaire developed by Zhang and Li (2004). The aim of this questionnaire was to test whether the subjects of the present study were autonomous or not. It had two parts including 21 questions. In the first part there were 11 items with 5 options for each in Likert scale from never to always and there were10 items in the second part for which the test takers were supposed to choose the closer answer to their beliefs and their attitudes. Both tests (Weir's test (1985), and Zhang \& Li's (2004)) had been proved to have high content validity and high reliability by their own designers.

\subsection{Procedures}

After homogenizing the participants by OPT, the questionnaire of autonomy was employed by the researchers to retrieve the Iranian EFL students' attitudes in the experimental group towards the extent to which they practice autonomously. The students were asked to finish the questions independently based on their own learning conditions for 30 minutes. The researchers attended the data collection session and to provided help with the participants and to make sure there would not be any ambiguity for the participants.

Next, a pre-test for critical thinking and finally a pre-test of writing were administered to both groups. Following that both groups received instruction for 12 weeks. The control group only received the conventional classroom instruction based on product-based approach. Students were supplied with a standard sample of text and they were expected to model and follow the standard to construct a new piece of writing. The instructor provided written feedbacks on participants' first draft writing and the participants had to revise their writing and hand in the final copy of writing.

On the contrary, in the experimental group students were taught to write using the Process-Based approach (Model of Herwins) which consists of five stages. In stage one or pre-writing, they were provided by a writing task and helped to 
generate vocabulary and ideas by applying a number of strategies in class like brainstorming. In stage two or first draft composing, they were asked to use vocabulary and ideas from the previous stage to express what they wanted to convey in their writing. In stage three or feedback, they received comment from the teacher or their peers and were asked to move on to new ideas in another draft. In stage four or second draft writing, students were asked to modify their previous draft by revising, adding, and rearranging ideas based on the comment they receive from the teacher or peers. Finally, in stage five or proofreading student were asked not only to discover new ideas and language forms to express their ideas in writing but also to focus on the appropriate use of vocabulary, layout, grammar and mechanics(O’Brien,2004).

After 12 weeks of instruction, the questionnaire of autonomy was administered to experimental group to check whether process-based approached affected the attitudes of the participant towards the extent the considered themselves autonomous. Furthermore, a post-test for critical thinking and writing were administered to the participants at both experimental and control groups. The objective of the post-tests, observations and questionnaire was to see whether the students have shown any change of behavior in these important factors and whether their writing ability had improved.

The data collected through OPT, critical thinking, and writing tests were put to statistical analysis using Statistic Package for Social Sciences (SPSS). In addition to calculating the descriptive statistics, independent sample $t$-test was run to see whether the participants' performances were statistically different on the post-tests. Moreover, Matched t-test was run to compare the participants' improvement on posttest compared to pretest.

\section{Data Analysis and Results}

\subsection{First Research Question}

As the first objective of the study, the participants' performance in writing was measured by a test of argumentative writing as a pre-test. A number of descriptive statistics such as mean, median, variance and standard deviation were calculated and incorporated in Table1.

Table 1. Descriptive Statistics for the Pre-Test Writing

\begin{tabular}{lllll}
\hline Groups & $\mathrm{N}$ & Mean & $\mathrm{SD}$ & SEM \\
\hline control & 30 & 11.3833 & 2.54675 & .46497 \\
experimental & 30 & 12.1583 & 2.95912 & .54026 \\
\hline
\end{tabular}

As it can clearly be seen in the above and table, there was a slight difference between the mean of control group $(\mathrm{M}=11.38)$ and that of experimental group $(\mathrm{M}=12.15)$.

In order to make sure whether the difference was significant or not, an independent sample t-test was run for pre-test of control and experimental groups. The results of the t-test on pre-test writings are displayed in Table 2.

Table 2. The Results of the $t$-test on the Pre-Test Writings

\begin{tabular}{|c|c|c|c|c|c|c|c|c|c|}
\hline & & \multicolumn{5}{|c|}{ Paired Differences } & \multirow[t]{3}{*}{$\mathrm{T}$} & \multirow[t]{3}{*}{ DF } & \multirow{3}{*}{$\begin{array}{l}\text { Sig. (2- } \\
\text { tailed) }\end{array}$} \\
\hline & & \multirow[t]{2}{*}{ Mean } & \multirow[t]{2}{*}{$\begin{array}{l}\text { Std. } \\
\text { Deviation }\end{array}$} & \multirow[t]{2}{*}{$\begin{array}{l}\text { Std. } \\
\text { Error } \\
\text { Mean }\end{array}$} & $\begin{array}{l}95 \% \\
\text { Interval } \\
\text { Difference }\end{array}$ & $\begin{array}{l}\text { Confidence } \\
\text { of the } \\
\text { e }\end{array}$ & & & \\
\hline & & & & & Lower & Upper & & & \\
\hline Pair & $\begin{array}{l}\text { Pre-test control group } \\
\text { and } \\
\text { pre-test experimental } \\
\text { group }\end{array}$ & .775 & 3.59762 & .65683 & 2.71837 & .03163 & 1.093 & 29 & .045 \\
\hline
\end{tabular}

The amount of $\mathrm{t}$-observed ( $\mathrm{t}$-observed=1.093), according to Table 2, was not significant at probability level of $\mathrm{p} \leq 0.01$; consequently, it could be claimed that the participants in the two groups were homogeneous concerning their ability in writing in English before instructions provided by the researchers.

Further analysis was applied to the scores of the post-test writings of the two groups to find out whether instruction and particularly the Process-Based Instruction had any effects on writing ability. Table 3 displays the descriptive Statistics for the post experiment writing.

Table 3. Descriptive Statistics for the Post-Test Writing

\begin{tabular}{lllll}
\hline Groups & $\mathrm{N}$ & Mean & SD & SEM \\
\hline Control & 30 & 12.1333 & 1.57941 & .28836 \\
experimental & 30 & 14.5833 & 2.04616 & .37358 \\
\hline
\end{tabular}


According to Table 3, both control group and experimental group had improved compared to their performances on pretest. However, there was a 2.45 mark difference between the means of the two groups. In order to understand whether this difference was statistically significant or not, the researchers employed another independent sample $t$-test. Table 4 reveals the results of $t$-test.

Table 4. The Results of the t-test on the Post-Test Writing

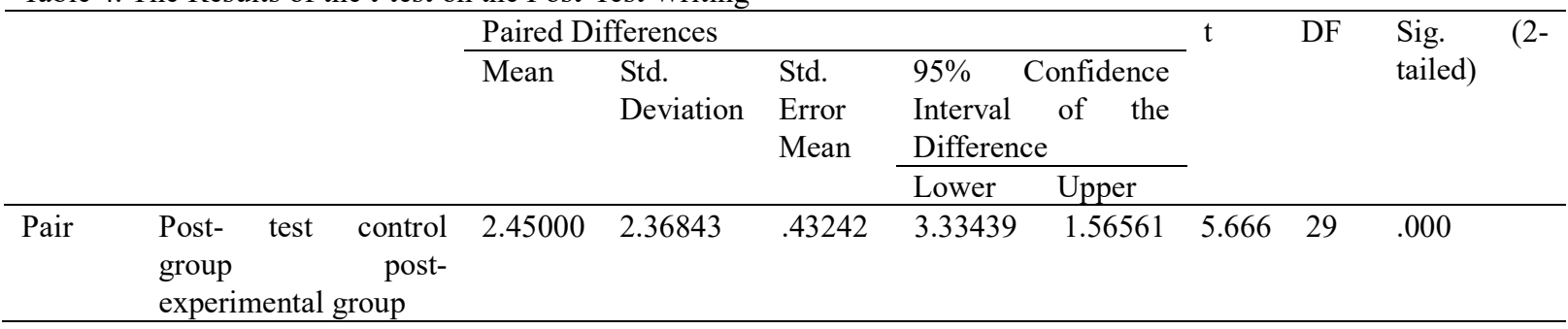

Based on Table 4, it could be observed that the amount of t-observed (t-observed $=5.666$ ) was significant at the probability level of $p \leq 0.01$. Put it differently, the participants who received Process-Based Instruction outperformed the control group and presented better writings. Therefore, the first null hypothesis stating that 'There is no significant difference between control and experimental groups in applying process-based approach for improving Iranian EFL students' writing skill' was safely rejected and it could be claimed that writing ability improvement is significantly more improved by Process-Based instruction compared to product-based instruction.

\subsection{Second Research Question}

Regarding the second research question, that is, to what extent does Process-Based approach in teaching writing enhance EFL learners' critical thinking ability, a critical thinking ability test was used to measure the participants' ability in terms of critical thinking. The results are displayed in Table 5.

Table 5. Descriptive Statistics for the Pre-Test Critical Thinking Test

\begin{tabular}{lllll}
\hline Groups & $\mathrm{n}$ & Mean & $\mathrm{SD}$ & $\mathrm{SEM}$ \\
\hline control & 30 & 10.4167 & 1.90545 & .34789 \\
experimental & 30 & 11.4333 & 2.00746 & .36651 \\
\hline
\end{tabular}

As revealed in table 5 participants' means were slightly different on pre-test critical thinking ability. Consequently, an independent sample $t$-test was conducted to compare the significance of participants' critical ability difference prior to instructions provided with both groups, as displayed in Table 6.

Table 6.The Results of the t-test on the Pre-Test critical thinking test

\begin{tabular}{|c|c|c|c|c|c|c|c|c|c|}
\hline & & \multicolumn{5}{|c|}{ Paired Differences } & \multirow[t]{5}{*}{$\mathrm{T}$} & \multirow[t]{5}{*}{ DF } & \multirow{5}{*}{$\begin{array}{l}\text { Sig. (2- } \\
\text { tailed) }\end{array}$} \\
\hline & & \multirow[t]{4}{*}{ Mean } & \multirow{4}{*}{$\begin{array}{l}\text { Std. } \\
\text { Deviation }\end{array}$} & \multirow{4}{*}{$\begin{array}{l}\text { Std. } \\
\text { Error } \\
\text { Mean }\end{array}$} & $95 \%$ & Confidence & & & \\
\hline & & & & & Interval & of the & & & \\
\hline & & & & & Difference & & & & \\
\hline & & & & & Lower & Upper & & & \\
\hline Pair & $\begin{array}{l}\text { Pre-test control group } \\
\text { pre-experimental group }\end{array}$ & 1.01667 & 2.72594 & .49769 & 2.03455 & .00122 & 2.043 & 29 & .050 \\
\hline
\end{tabular}

According to Table 6, the difference between the two groups was not significant at probability level of $\mathrm{p} \leq 0.01$ as set by the researchers.

More analysis was applied to the scores of the post-test critical thinking tests of the two groups to realize if the ProcessBased instruction had any effects on critical thinking ability. Table 7 shows the descriptive statistics for the post-test critical thinking tests.

Table 7. Descriptive Statistics for the Post-Test Critical Thinking Test

\begin{tabular}{lllll}
\hline Groups & $\mathrm{N}$ & Mean & SD & SEM \\
\hline control & 30 & 10.9000 & 1.66298 & .30362 \\
experimental & 30 & 12.7833 & 1.88658 & .34444 \\
\hline
\end{tabular}

Based on Table 7 there is a 1.88 mark difference between the means of the two groups. Therefore, as to understand 
Table 8. The Results of the t-test on the Post-Test critical thinking test

\begin{tabular}{|c|c|c|c|c|c|c|c|c|c|}
\hline & & \multicolumn{5}{|c|}{ Paired Differences } & \multirow[t]{3}{*}{$\mathrm{T}$} & \multirow[t]{3}{*}{ DF } & \multirow{3}{*}{$\begin{array}{l}\text { Sig. } \\
\text { tailed) }\end{array}$} \\
\hline & & \multirow[t]{2}{*}{ Mean } & \multirow[t]{2}{*}{$\begin{array}{l}\text { Std. } \\
\text { Deviation }\end{array}$} & \multirow[t]{2}{*}{$\begin{array}{l}\text { Std. Error } \\
\text { Mean }\end{array}$} & $\begin{array}{l}95 \% \\
\text { Interval } \\
\text { Difference }\end{array}$ & $\begin{array}{l}\text { Confidence } \\
\text { of the }\end{array}$ & & & \\
\hline & & & & & Lower & Upper & & & \\
\hline $\begin{array}{l}\text { Pair } \\
1\end{array}$ & $\begin{array}{l}\text { Post-test } \quad \text { control } \\
\text { group post- } \\
\text { experimental group }\end{array}$ & 1.88333 & 2.19888 & .40146 & 2.70441 & 1.06226 & 3.691 & 29 & .000 \\
\hline
\end{tabular}

According to Table 8, it could be observed that the amount of t-observed (t-observed $=3.691$ ) was significant at the probability level of $\mathrm{p} \leq 0.01$. Differently stated, the participants who received Process-Based instruction outperformed the control group and demonstrated better critical thinking abilities. As a result, the second null hypothesis stating that 'there is no significant difference between Iranian EFL students' critical thinking ability taught writing skill through process-based approach and those taught conventionally' was safely rejected and it could be claimed that critical thinking ability was positively affected by Process-Based instruction.

\subsection{Third Research Question}

A research questionnaire was used to find out whether there is any significant difference between Iranian EFL students' attitudes towards the extent they considered themselves autonomous before and after process-based instruction. The questionnaire consisted of two parts including 21 items. The first part included 11 items in a five-point Likert scale. The second part of the questionnaire consisted of 10 items in multiple choice format.

In order to provide a clearer presentation of the data the items in the first part of the questionnaire were compared before and after the implementation process-based instruction. Table 9 and Table 10 display the results of the questionnaire before the implementation of Process-Based approach.

Table 9. The results of first part of questionnaire before the implementation of the Process-Based approach

\begin{tabular}{|c|c|c|c|c|c|c|c|c|}
\hline & Questions & & Never & Rarely & Sometimes & Often & Always & Mean \\
\hline \multirow{2}{*}{1} & \multirow{2}{*}{$\begin{array}{l}\text { I think I have the ability to learn English } \\
\text { well. }\end{array}$} & Frequency & 4 & 9 & 13 & 3 & 1 & \multirow{2}{*}{1.60} \\
\hline & & Percentage & 13.33 & 30 & 43.33 & 10 & 3.33 & \\
\hline \multirow{2}{*}{2} & \multirow{2}{*}{$\begin{array}{l}\text { I make good use of my free time in } \\
\text { English study. }\end{array}$} & Frequency & 7 & 11 & 9 & 3 & 0 & \multirow{2}{*}{1.26} \\
\hline & & Percentage & 23.33 & 36.66 & 30 & 10 & 0 & \\
\hline \multirow{2}{*}{3} & \multirow{2}{*}{ I preview before the class. } & Frequency & 7 & 8 & 10 & 4 & 1 & \multirow{2}{*}{1.46} \\
\hline & & Percentage & 23.33 & 26.66 & 33.33 & 13.33 & 3.33 & \\
\hline \multirow{2}{*}{4} & \multirow{2}{*}{ I find I can finish my task in time } & Frequency & 4 & 9 & 9 & 5 & 3 & \multirow{2}{*}{1.80} \\
\hline & & Percentage & 13.33 & 30 & 30 & 16.66 & 10 & \\
\hline \multirow{2}{*}{5} & \multirow{2}{*}{$\begin{array}{l}\text { I keep a record of my study, such as } \\
\text { keeping a diary, writing review etc. }\end{array}$} & Frequency & 5 & 8 & 11 & 5 & 1 & \multirow{2}{*}{1.63} \\
\hline & & Percentage & 16.66 & 26.66 & 36.66 & 16.66 & 3.33 & \\
\hline \multirow{2}{*}{6} & \multirow{2}{*}{$\begin{array}{l}\text { I make self-exam with the exam papers } \\
\text { chosen by myself. }\end{array}$} & Frequency & 3 & 5 & 15 & 3 & 4 & \multirow{2}{*}{2.00} \\
\hline & & Percentage & 10 & 16.66 & 50 & 10 & 13.33 & \\
\hline \multirow{2}{*}{7} & \multirow{2}{*}{$\begin{array}{l}\text { I reward myself such as going shopping, } \\
\text { playing etc. When I make progress. }\end{array}$} & Frequency & 0 & 6 & 12 & 11 & 1 & \multirow{2}{*}{2.23} \\
\hline & & Percentage & 0 & 20 & 40 & 36.66 & 3.33 & \\
\hline \multirow{2}{*}{8} & \multirow{2}{*}{$\begin{array}{l}\text { I attend out-class activities to practice and } \\
\text { learn the language. }\end{array}$} & Frequency & 3 & 7 & 6 & 9 & 5 & \multirow{2}{*}{2.20} \\
\hline & & Percentage & 10 & 23.33 & 20 & 30 & 16.67 & \\
\hline \multirow[b]{2}{*}{9} & \multirow{2}{*}{$\begin{array}{l}\text { During the class, I try to catch chances to } \\
\text { take part in activities such as pair/group } \\
\text { discussion, role-play, etc. }\end{array}$} & Frequency & 3 & 9 & 9 & 7 & 2 & \multirow[b]{2}{*}{1.86} \\
\hline & & Percentage & 10 & 23.33 & 20 & 30 & 16.66 & \\
\hline \multirow{2}{*}{10} & \multirow{2}{*}{$\begin{array}{l}\text { I know my strengths and weaknesses in } \\
\text { my English study. }\end{array}$} & Frequency & 3 & 6 & 9 & 8 & 4 & \multirow{2}{*}{2.13} \\
\hline & & Percentage & 10 & 30 & 30 & 23.33 & 6.66 & \\
\hline \multirow{3}{*}{11} & \multirow{2}{*}{$\begin{array}{l}\text { I choose books, exercises which suit me, } \\
\text { neither too difficult nor too easy. }\end{array}$} & Frequency & 1 & 6 & 10 & 9 & 4 & \multirow{2}{*}{2.36} \\
\hline & & Percentage & 3.33 & 20 & 33.33 & 30 & 13.33 & \\
\hline & & & & & & Total $\mathrm{N}$ & lean & 0.68 \\
\hline
\end{tabular}

According to Table 9 the means score of the first, second, third, fourth, fifth, and the ninth items were 1.60, 1.26, 1.46, $1.80,1.63$ and 1.86 respectively. This would mean that the learners did not do the relevant activity adequately to be 
considered autonomous and independent. On the other hand the means score for items six, seven, eight, ten and eleven were $2.00,2.23,2.20,2.13$, and 2.36 respectively. The means reveal that the participants were engaged in the relevant activity before the implementation of the Process-Based approach.

Table10. The results of first part of questionnaire after the implementation of the Process-Based approach

\begin{tabular}{|c|c|c|c|c|c|c|c|c|}
\hline & Questions & & Never & Rarely & Often & Sometime & Always & Mean \\
\hline \multirow{2}{*}{1} & \multirow{2}{*}{$\begin{array}{l}\text { I think I have the ability to learn } \\
\text { English well. }\end{array}$} & Frequency & 2 & 7 & 14 & 6 & 1 & \multirow[b]{2}{*}{1.90} \\
\hline & & Percentage & 6.66 & 23.33 & 46.66 & 20 & 3.33 & \\
\hline \multirow{2}{*}{2} & \multirow{2}{*}{$\begin{array}{l}\text { I make good use of my free time in } \\
\text { English study. }\end{array}$} & Frequency & 2 & 12 & 12 & 4 & 0 & \multirow{2}{*}{1.60} \\
\hline & & Percentage & 6.66 & 40 & 40 & 13.33 & 0 & \\
\hline \multirow{2}{*}{3} & \multirow{2}{*}{ I preview before the class. } & Frequency & 2 & 7 & 13 & 7 & 1 & \multirow{2}{*}{1.93} \\
\hline & & Percentage & 6.66 & 23.33 & 43.33 & 23.33 & 3.33 & \\
\hline \multirow{2}{*}{4} & \multirow{2}{*}{ I find I can finish my task in time } & Frequency & 1 & 8 & 10 & 7 & 4 & \multirow{2}{*}{2.16} \\
\hline & & Percentage & 3.33 & 26.66 & 33.33 & 23.33 & 13.33 & \\
\hline \multirow{2}{*}{5} & \multirow{2}{*}{$\begin{array}{l}\text { I keep a record of my study, such as } \\
\text { keeping a diary, writing review etc. }\end{array}$} & Frequency & 3 & 8 & 8 & 7 & 4 & \multirow{2}{*}{2.03} \\
\hline & & Percentage & 10 & 26.66 & 26.66 & 23.33 & 13.33 & \\
\hline \multirow{2}{*}{6} & \multirow{2}{*}{$\begin{array}{l}\text { I make self-exam with the exam } \\
\text { papers chosen by myself. }\end{array}$} & Frequency & 1 & 4 & 14 & 6 & 5 & \multirow{2}{*}{2.33} \\
\hline & & Percentage & 3.33 & 13.33 & 46.66 & 20 & 16.66 & \\
\hline \multirow[b]{2}{*}{7} & \multirow{2}{*}{$\begin{array}{l}\text { I reward myself such as going } \\
\text { shopping, playing etc. When I make } \\
\text { progress. }\end{array}$} & Frequency & 2 & 3 & 13 & 11 & 1 & \multirow[b]{2}{*}{2.36} \\
\hline & & Percentage & 6.66 & 10 & 43.33 & 36.66 & 3.33 & \\
\hline \multirow{2}{*}{8} & \multirow{2}{*}{$\begin{array}{l}\text { I attend out-class activities to practice } \\
\text { and learn the language. }\end{array}$} & Frequency & 0 & 8 & 6 & 9 & 7 & \multirow{2}{*}{2.50} \\
\hline & & Percentage & 0 & 26.67 & 20 & 30 & 23.33 & \\
\hline \multirow[b]{2}{*}{9} & \multirow{2}{*}{$\begin{array}{l}\text { During the class, I try to catch } \\
\text { chances to take part in activities such } \\
\text { as pair/group discussion, role-play, } \\
\text { etc. }\end{array}$} & Frequency & 0 & 7 & 12 & 8 & 3 & \multirow[b]{2}{*}{2.23} \\
\hline & & Percentage & 0 & 26.66 & 20 & 30 & 23.33 & \\
\hline \multirow{2}{*}{10} & \multirow{2}{*}{$\begin{array}{l}\text { I know my strengths and weaknesses } \\
\text { in my English study. }\end{array}$} & Frequency & 1 & 5 & 10 & 10 & 4 & \multirow{2}{*}{2.36} \\
\hline & & Percentage & 0 & 23.33 & 40 & 26.66 & 10 & \\
\hline \multirow{2}{*}{11} & \multirow{2}{*}{$\begin{array}{l}\text { I choose books, exercises which suit } \\
\text { me, neither too difficult nor too easy. }\end{array}$} & Frequency & 0 & 5 & 10 & 9 & 6 & \multirow{2}{*}{2.53} \\
\hline & & Percentage & 0 & 0 & 0 & 0 & 0 & \\
\hline & & & & & & Total Mean & & 0.79 \\
\hline
\end{tabular}

According to Table 10, the means score of the first, second, and the third items were 190, 1.60, and 1.93 respectively, which were greater than the means score of the corresponding items before introducing the treatment, that is the use of Process-Based approach. It implies that the treatment has fostered the autonomy of participants to some extent. On the other hand, the means score for items four, five, six, seven, eight, nine, ten and eleven were 2.16, 2.03, 2.33, 2.36, 2.50, $2.23,2.36$, and 2.53 respectively; the participants performance on the above items had improved compared to their performance on the same items before the administration of treatment. That is to say the students were more autonomous compared to the time when had not been taught through Process-Based Method.

To see to what extent applying the Process-Based approach had improved learners' autonomy and their independency, the total mean score $(\mathrm{M}=.68)$ of the participants in the experimental group before the implementation of the ProcessBased approach was compared with their total mean score $(M=.78)$ after the treatment. There was a difference between the means before and after the treatment as reported in Table 9 and 10. In order to make sure whether the difference is statistically significant or not, the researchers employed a matched t-test. Table 11 shows the results of matched t-test for the comparison of participants before and after the implementation of treatment.

Table 11. Matched t-test results of first part of questionnaire of learners' autonomy before and after the implementation of treatment

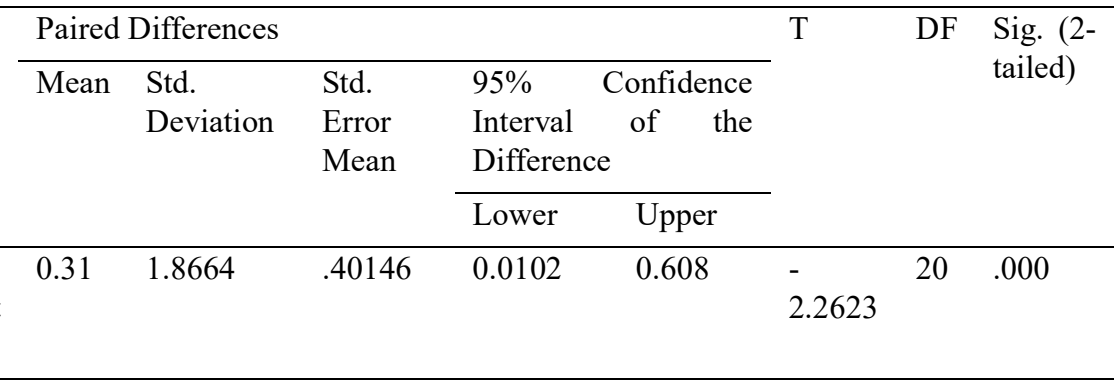


As displayed in Table 11, the mean difference is significant before and after the implementation of treatment, $\mathrm{t}(20)=-$ $2.2623, \mathrm{p} \leq 0.05$. Therefore, the learners who underwent Process-Based instruction were considered more autonomous than they were before the implementation of the Process-Based approach.

The second part of the questionnaire contained 10 items in multiple choice format to find out the students attitudes' regarding the extent to which they considered themselves autonomous before and after the implementation of the Process-Based instruction.

Table 12. The results the second part of questionnaire before the implementation of the Process-Based approach

\begin{tabular}{|c|c|c|c|c|c|c|c|}
\hline Item & Questions & & A & $\mathrm{B}$ & $\mathrm{C}$ & $\mathrm{D}$ & $\mathrm{E}$ \\
\hline \multirow{3}{*}{12} & \multirow{3}{*}{ I study English here due to: } & Frequency & 4 & 9 & 13 & 3 & 1 \\
\hline & & Percentage & 13.33 & 30 & 43.33 & 20 & 3.33 \\
\hline & & Score & 1 & 2 & 3 & 4 & 5 \\
\hline \multirow{3}{*}{13} & \multirow{3}{*}{ I think the learner-teacher relationship is that of: } & Frequency & 8 & 5 & 7 & 8 & 2 \\
\hline & & Percentage & 26.67 & 16.67 & 23.33 & 26.67 & 6.67 \\
\hline & & Score & 1 & 4 & 2 & 3 & 5 \\
\hline \multirow{3}{*}{14} & \multirow{3}{*}{$\begin{array}{l}\text { I think my success or failure in English study is mainly } \\
\text { due to: }\end{array}$} & Frequency & 6 & 7 & 4 & 8 & 5 \\
\hline & & Percentage & 20 & 23.33 & 13.33 & 26.67 & 16.67 \\
\hline & & Score & 1 & 3 & 4 & 2 & 5 \\
\hline \multirow{3}{*}{15} & \multirow{3}{*}{$\begin{array}{l}\text { Whether students should design the teaching plan } \\
\text { together with teachers or not, my opinion is: }\end{array}$} & Frequency & 3 & 3 & 10 & 10 & 4 \\
\hline & & Percentage & 10 & 10 & 33.33 & 33.33 & 13.33 \\
\hline & & Score & 5 & 4 & 3 & 2 & 1 \\
\hline \multirow{3}{*}{16} & \multirow{3}{*}{$\begin{array}{l}\text { When the teacher asks questions for us to answer, I } \\
\text { would mostly like to: }\end{array}$} & Frequency & 5 & 5 & 6 & 7 & 7 \\
\hline & & Percentage & 16.67 & 16.67 & 20 & 23.33 & 23.33 \\
\hline & & Score & 1 & 5 & 4 & 3 & 2 \\
\hline \multirow{3}{*}{17} & \multirow{3}{*}{ When I meet a word I don't know, I mainly: } & Frequency & 7 & 2 & 4 & 10 & 7 \\
\hline & & Percentage & 23.33 & 6.67 & 13.33 & 33.33 & 23.33 \\
\hline & & Score & 1 & 2 & 5 & 3 & 4 \\
\hline \multirow{3}{*}{18} & \multirow{3}{*}{$\begin{array}{l}\text { When I make mistakes in study, I'd usually like the } \\
\text { following ones to correct them: }\end{array}$} & Frequency & 4 & 4 & 8 & 10 & 4 \\
\hline & & Percentage & 13.33 & 13.33 & 26.67 & 33.33 & 13.33 \\
\hline & & Score & 1 & 4 & 2 & 3 & 5 \\
\hline \multirow{3}{*}{19} & \multirow{3}{*}{$\begin{array}{l}\text { When I am asked to use technologies that I haven't used } \\
\text { before (e. g. internet discussion), }\end{array}$} & Frequency & 3 & 4 & 9 & 3 & 11 \\
\hline & & Percentage & 10 & 13.33 & 30 & 10 & 36.67 \\
\hline & & Score & 5 & 4 & 3 & 1 & 2 \\
\hline \multirow{3}{*}{20} & \multirow{3}{*}{$\begin{array}{l}\text { I think the following way is most useful in my English } \\
\text { study: }\end{array}$} & Frequency & 4 & 8 & 1 & 12 & 5 \\
\hline & & Percentage & 13.33 & 26.67 & 3.33 & 10 & 16.67 \\
\hline & & Score & 4 & 1 & 2 & 3 & 5 \\
\hline \multirow{3}{*}{21} & \multirow{3}{*}{ I usually use materials selected: } & Frequency & 0 & 8 & 12 & 5 & 5 \\
\hline & & Percentage & 0 & 26.66 & 40 & 16.67 & 16.67 \\
\hline & & Score & 1 & 2 & 3 & 5 & 4 \\
\hline
\end{tabular}

As for item 12 'I study English here due to' most of the participants (43.33\%) reported that getting a good job that would help their major was the main reason why they studied English. Around 30 percent of the participants believed that curiosity was the main impetus for studying English. The interest for English culture, films, sports, music, etc., made 20 percent of participants' reason. And, some 13.33 percent of the learners stated that they study English because of their parent's demand.

As for item 13, 'I think the learner-teacher relationship is that of' most of the students (26.26\%) reported their relations with the teacher as partners and also as receiver and giver. Around 23.33 percent believed the teacher-relationship is a sort of customer and shopkeeper relationship. Some 16.67 percent of the learners described the relationship as raw material and maker. And, some 6.67 percent of the students stated explorer and director can best describe their relationships with the teacher.

Regarding item 14, 'I think my success or failure in English study is mainly due to' most of the subjects (26.67\%) reported teachers as the main reason for success or failure. Around 23.33 percent of the learners believed English studying environment plays the key role in success and failure. Luck or fate made 20 percent of participants' reason. Some 16.67 percent of the students stated myself. And, studying facilities (aids) was 13.33 percent of the learner's reason for their success or failure in English studying.

For item 15, 'whether students should design the teaching plan together with teachers or not', most of the learners reported for both options neutral and oppose, each registering (33.33\%) respectively. Around 13.33 percent stated strongly oppose. The options strongly agree and agree registered 10 percent each.

For item 16, 'when teacher asks questions for us to answer', most of the students reported they would mostly like to clarify questions with teachers (23.33\%), and they would mostly like to join a pair/group discussion (23.33\%). Around 
20 percent of the learners believed that looking up books, dictionaries were the main way to answer teachers' questions. The options that they wait for others answers and they think and get ready to answer, were selected each by 16.67 of participants as the ways they reacted to teacher's questions.

For item 17, 'when I meet a word I don't know, I mainly' most participants of the study (33.33\%) reported that they asked others or look up the dictionary. Both options letting it go and looking up the dictionary each registered 23.33 percent of the participants 'choices. Some 13.33 percent of the students reported that they guess the meaning. Asking others when they met a word that they didn't know made 6.67 percent of the participants idea.

For item 18, 'when I make mistakes in study, I'd usually like the following ones to correct them', most of the learners (36.67\%) reported others. Around 26.67 percent of the students would like that their classmate correct them. The options letting them be, teacher and books or dictionaries each one made up 13.33 percent of the participants' choices.

For item 19, 'when I am asked to use technologies that I haven't used before (e.g. internet discussion)' most of the learners (36.67\%) reported that they resisted using them. Around 30 percent of the participants felt worried when they were asked to use technologies. Some 13.33 percent of the subjects of the study stated that they learn them following others. Some 10 percent claimed separately for both options trying to learn new skills, another 10 percent stated they put it off or try to avoid it when they were asked to use technologies.

For item 20, 'I think the following way is most useful in my English study' most of the learners (26.67\%) reported mechanic memory. Around 16.67 percent of the participants believed group discussion was most useful in their English study. Taking notes made 13.33 percent of learners' belief. Classifying or comparing made 10 percent of the participants' idea. Some 3.33 percent of the learners stated that doing exercises of grammar, translation, word set was most useful way in their English study.

As for item 21, 'I usually use materials selected by...' most of the students (40\%) reported by their teachers and by themselves. Around 26.66 percent of the learners used materials selected mostly by their teachers. Some 16.67 percent of the participants selected the option mostly by themselves, and 16.67 percent selected materials by only themselves.

In order to see whether the autonomy level of participants in the experimental group changed after they were exposed to process-based instruction, the same questionnaire was used again. Table 13 shows the frequency of each item after the treatment.

Table 13. The results the second part of questionnaire after the implementation of the Process-Based approach

\begin{tabular}{|c|c|c|c|c|c|c|c|}
\hline & Questions & & A & $\mathrm{B}$ & $\mathrm{C}$ & $\mathrm{D}$ & $E$ \\
\hline \multirow{3}{*}{12} & \multirow{3}{*}{ I study English here due to: } & Frequency & 3 & 8 & 14 & 4 & 1 \\
\hline & & Percentage & 10 & 26.67 & 46.67 & 13.33 & 3.33 \\
\hline & & Score & 1 & 2 & 3 & 4 & 5 \\
\hline \multirow{3}{*}{13} & \multirow{3}{*}{$\begin{array}{l}\text { I think the learner-teacher } \\
\text { relationship is that of: }\end{array}$} & Frequency & 7 & 5 & 7 & 9 & 2 \\
\hline & & Percentage & 23.33 & 16.67 & 23.33 & 30 & 6.67 \\
\hline & & Score & 1 & 4 & 2 & 3 & 5 \\
\hline \multirow{3}{*}{14} & \multirow{3}{*}{$\begin{array}{l}\text { I think my success or failure in } \\
\text { English study is mainly due to: }\end{array}$} & Frequency & 3 & 7 & 5 & 9 & 6 \\
\hline & & Percentage & 10 & 23.33 & 16.67 & 30 & 20 \\
\hline & & Score & 1 & 3 & 4 & 2 & 5 \\
\hline \multirow{3}{*}{15} & \multirow{3}{*}{$\begin{array}{l}\text { Whether students should design } \\
\text { the teaching plan together with } \\
\text { teachers or not, my opinion is: }\end{array}$} & Frequency & 3 & 7 & 10 & 8 & 2 \\
\hline & & Percentage & 10 & 23.33 & 33.33 & 26.67 & 6.67 \\
\hline & & Score & 5 & 4 & 3 & 2 & 1 \\
\hline \multirow{3}{*}{16} & \multirow{3}{*}{$\begin{array}{l}\text { When the teacher asks questions } \\
\text { for us to answer, I would mostly } \\
\text { like to: }\end{array}$} & Frequency & 5 & 5 & 6 & 8 & 6 \\
\hline & & Percentage & 16.67 & 16.67 & 20 & 26.67 & 20 \\
\hline & & Score & 1 & 5 & 4 & 3 & 2 \\
\hline \multirow{3}{*}{17} & \multirow{3}{*}{$\begin{array}{l}\text { When I meet a word I don't know, } \\
\text { I mainly: }\end{array}$} & Frequency & 5 & 4 & 6 & 10 & 5 \\
\hline & & Percentage & 16.67 & 13.33 & 20 & 33.33 & 16.67 \\
\hline & & Score & 1 & 2 & 5 & 3 & 4 \\
\hline \multirow{3}{*}{18} & \multirow{3}{*}{$\begin{array}{l}\text { When I make mistakes in study, } \\
\text { I'd usually like the following ones } \\
\text { to correct them: }\end{array}$} & Frequency & 2 & 5 & 7 & 12 & 4 \\
\hline & & Percentage & 6.67 & 16.67 & 23.33 & 40 & 13.33 \\
\hline & & Score & 1 & 4 & 2 & 3 & 5 \\
\hline \multirow{3}{*}{19} & \multirow{3}{*}{$\begin{array}{l}\text { When I am asked to use } \\
\text { technologies that I haven't used } \\
\text { before (e. g. internet discussion), }\end{array}$} & Frequency & 4 & 5 & 9 & 3 & 9 \\
\hline & & Percentage & 13.33 & 16.67 & 30 & 10 & 30 \\
\hline & & Score & 5 & 4 & 3 & 1 & 2 \\
\hline \multirow{3}{*}{20} & \multirow{3}{*}{$\begin{array}{l}\text { I think the following way is most } \\
\text { useful in my English study: }\end{array}$} & Frequency & 4 & 6 & 6 & 12 & 2 \\
\hline & & Percentage & 13.33 & 20 & 20 & 40 & 6.67 \\
\hline & & Score & 4 & 1 & 2 & 3 & 5 \\
\hline \multirow{3}{*}{21} & \multirow{3}{*}{ I usually use materials selected: } & Frequency & 0 & 7 & 13 & 5 & 5 \\
\hline & & Percentage & 0 & 23.33 & 43.33 & 16.67 & 16.67 \\
\hline & & Score & 1 & 2 & 3 & 5 & 4 \\
\hline
\end{tabular}


After the implementation of treatment, in reaction to item 12, getting a good job that would help their major as the most frequent reason chosen by participants why they studied English. It seems that promoting carrier opportunity is the best reason they study English and Process-Based Instruction has improved the tendency as an indication of autonomy.

As for item 13, the most powerful options showing the autonomy of students are the options raw material and maker (B), partners (D), and explorer and director (E). Before applying the treatment these options altogether made up 50.01\% of participants' choices. However, as the most powerful indexes of autonomy, options D, B, and E made up 53.34\% of participants choices. The increase indicates that participants were more intended to be autonomous after the implementation of treatment and they had upgraded.

As for item 14, the most powerful options stating the autonomy of students are options English studying environment (B), studying facilities (aids) (C), and myself (E). Before the implementation of Process-Based approach options B, C and $\mathrm{E}$ were selected by 53.33 percent of students. However, after applying the treatment these options made up $60 \%$ of participants choices. The increase indicates that participants were more intended to be autonomous after exposing to process-based instruction.

As for item 15, the most powerful options indicating the autonomy of students are options strongly agree (A), agree (B), and neutral $(C)$. Before using the treatment, these options altogether made up $53.33 \%$ of participants choices. However, as the most powerful indexes of autonomy these options made up $66.66 \%$ of subjects choices. The increase indicates that students were more intended to be autonomous and they had improved after using the treatment.

As for item 16, the most autonomous options indicating the autonomy of participants are options think and ready to answer(B), look up books, dictionaries $(C)$, and: clarify questions with teacher(D) respectively. Before the implementation of treatment options B, C, and D were selected by the participants altogether as $60 \%$ of their choices. However, as the most powerful indexes of autonomy options B, C, and D made up $63.34 \%$ of participants choices. The increase indicates that participants were more intended to be autonomous after the implementation of treatment.

As for item 17, the most powerful options showing the autonomy of students are options ask others and look up the dictionaries $(D)$, look up the dictionaries $(E)$, and guesses the meaning $(C)$ respectively. Before applying the ProcessBased approach options D, E, and C were selected by the subjects altogether as $69.99 \%$ of their choices. However, as the most powerful indexes of autonomy these options made up $70 \%$ of students choices after using the treatment which indicates that participants were slightly more intended to be autonomous.

In reaction to item 18 , the most powerful options indicating the autonomy of students are options: teachers $(B)$, others (D), and books or dictionaries (E). Before Writing Process-Based Instruction these options were selected by the students' altogether as $59.99 \%$ of options available for item 18 . However, as the most powerful indexes of autonomy options B, D, and E made up 70\% of subject choices after using the treatment. The increase indicates that participants were more intended to be autonomous and they had progressed.

As for item 19, the most powerful options indicating the autonomy of subjects are the options I usually try to learn new skills (A), I learn them following others (B), and I feel worried (C). Before using the treatment, options A, B, and C were selected by the participants as $53.33 \%$ of their choices. However, these options made up $60 \%$ of students choices. The increase shows that students were more intended to be autonomous and they had improved.

In reaction to item 20, the most powerful options showing the autonomy of participants are options taking notes (A), classifying or group comparing (D), and group discussion $(E)$. Before teaching Process-Based Instruction options A, D, and E were made up altogether $40 \%$ of options available for item 20 .However, these options made up $60 \%$ of their choices. This increase states that subjects were more tended to be autonomous and they had upgraded after using the treatment.

As for the last item, the most powerful options indicating the autonomy of the subjects of the study are options: by teachers and by myself $(C)$, mostly by myself $(D)$, and only by myself $(E)$. Before applying the instruction these options were selected by students altogether as $73.34 \%$ of their choices. However, options C, D, and E amounted to $76.67 \%$ of participants' choices. This increase indicates that students were more intended to be autonomous after using the treatment.

\section{Discussion}

The obtained results and findings of the current study possess the ability to lead to the conclusions which are undoubtedly of high importance. To this end, the present study aimed to answer three questions. The first one was 'To what extent does Iranian EFL students' writing skill improve by applying process-based approach in teaching writing skill?'. To answer this, students were taught to write using the Process-Based approach which consists of five stages. In fact, the Process-Based approach is a teaching approach that concentrates on the processes a writer undertakes when constructing meaning. Unlike the Product-Based approach this teaching approach ends with editing as a final stage in text creation. The Process-Based approach may consist of recognized stages of the writing process like pre-writing, writing and re-writing and it involves peer and teacher conferencing (Murray, 1972).

After comparing the results of the experimental group performance and those of the control group, the researcher came to the conclusion that these two groups were significantly different. In other words, the group undergoing the ProcessBased instruction outperformed the control group. Consequently, through the data gathered the first null hypothesis was rejected and it was found that Process-Based approach affect writing ability in a positive way. This finding adds to a growing body of research that has investigated the effect of Process-Based approach on writing performance. The 
findings of the present study are in line with those of other researches that teaching the group of writing techniques recognized together as writing process is related to higher average writing proficiency among students (Elbow, 1973; Graves, 1983; Murray, 1985; Sommers, 1982, Goldstein \& Carr, 1996, Croes, 1990, Harris, 1992, De La Paz \& Graham, 2002). In addition, these findings are in agreement with Dean and Rumsey (1998) who stated that explicitly teaching the Process-Based approach to the students has positive impact on enhancing their writing proficiency. Also, in line with previous studies (Bruno,1983), the present study found that the writing of students taught using the Process-Based approach was superior compared with the students using the traditional method and this was particularly the case in terms of the overall organization and format.

Concerning the second question which asked 'To what extent dose process-based approach in teaching writing skill improve Iranian EFL learners' critical thinking ability?', the results revealed that the students in the experimental group performed better than the control group. Consequently, the second null hypothesis was rejected and it was found that Process-Based approach affects critical thinking ability. This is in line with Paul and Elder (2003) findings that ProcessBased Writing possesses the characteristics which are used in critical thinking and since Process-Based Writing encourages problem-solving and critical reasoning it can increase critical thinking ability.

Regarding the third research question, asking 'is there any significant difference between Iranian EFL students' attitudes towards the extent they considered themselves autonomous before and after process-based instruction?' the results provided an affirmative reply. In other words, the students undergoing the Process-Based instruction showed positive changes in their self-learning capability before and after the instruction and it played a role in enhancing the learners' learning autonomy. These findings were in agreement with the research of Benson (2001) and Wendi (2002). The results are also compatible with the theory that possessing some degree of autonomy is necessary if learners are to become efficient language users (Nunan, 1995; Hyland, 2002; Breen, 1984; Littlewoods, 1996).

Furthermore, the results are particularly important in the Iranian context since the traditional teacher-centered method which is characterized by rote learning and memorization of target language rules are still applied by Iranian teachers (Kashef, Viyani, Ghabool \& Damavand, 2012). Indeed, the English language classrooms in Iran which lack or have inadequate student-teacher interaction is far from being conducive to fostering autonomy.

As a result, it is hoped that Process-Based approach as a learning-centered approach that pays attention to the learners' needs and learning processes and considers their appropriate skills and techniques be applied by the Iranian teachers to help students accomplish their goals in the area of writing. Indeed, the results of the current study support the application of a process-based approach for enhancing learners' autonomy as opposed to the teacher-centered classes.

In the final run, it is suggested that EFL teachers in Iran focus on Process-Based instruction. In fact, in order to enhance the writing proficiency, critical thinking ability and autonomy of Iranian students the teaching of process-based approach should be an indispensable part of the English language teaching (ELT) program in Iranian high schools and universities.

\section{Conclusion and Pedagogical Implications}

Even though writing is vitally important in both academic and daily lives of people, the majority of students suffer from difficulties of writing in a foreign language. Writing plays a role as a communicative tool through which international trade and diplomacy are done, scientific and technological advancements are emphasized and news and information are disseminated (Crystal, 1997, 2000; Graddol, 1997). Among the four language skills, writing is the most complex and difficult skill to master. As said by Richards and Renandya (2002, p. 303), "this difficulty is not only in organizing of ideas but also in translating these ideas into readable texts". Hence, there is a need to use a method that increases the EFL students writing ability. Therefore, the current study was an attempt to investigate how Process-Based approach in teaching writing impacts Iranian EFL learners' writing ability. The findings imply that the Process-Based approach increases the writing proficiency and students who undergo it are more likely to achieve high writing proficiency.

Furthermore, one of the chief inadequacies of Iranian institutions is lack of a systematic and efficient program for teaching critical thinking. Consequently, Iranian students lose their self-confidence and innate sense of curiosity which are the two vital necessities for their growth and development (Bazrafkan \& Bagheri, 2014). The results of this study showed that applying Process-Based Instruction increased learner's critical thinking. Thus, it can be used by Iranian EFL teachers to increase learners' critical thinking ability.

In addition, autonomy is essential for efficient learning to happen and writing is an important modality of language acquisition. Indeed, learner autonomy in the learning of writing is indubitably a desired goal (Hyland, 2002).This is particularly important in the Iranian context since we have seen that Iranian students are raised in a way that their study directs them only to be followers and rote learners (Riazi, 2005; Borjian, 2009; Farhady \& Hedayati, 2009; Farhady et al., 2010). The results of the study indicated that the students' autonomy improved significantly and positively through the application of the process-based approach.

Through showing how the Process-Based approach contributed to the development of students writing ability, critical thinking and autonomy, the study hopefully helps in supplying evidence in support of this teaching approach in Iranian EFL classrooms. 


\section{References}

Applebee, A. N. (1986). Problems in process approaches: Toward a reconceptualization of process instruction. In A. R. Petrosky and D. Bartholomae (Eds.), the teaching of writing. Chicago, Ill: National Society for the study of Education.

Bell, J. \& Burnaby, B. (1984). A Handbook for ESL Literacy. Toronto: OISE.

Benson, P. (2001). Concepts of autonomy in language learning. In R. Pemberton, E. S. L. Li, W. W. F. Or, \& H. D. Pierson (Eds.), Taking control: Autonomy in language learning (pp. 27-34). Hong Kong: Hong Kong University Press.

Borjian, M. (2009). English education in post-revolutionary Iran (1979-2008): The politics of educational borrowing and lending. Unpublished doctoral dissertation. Columbia University, United States of America.

Breen, M. (1984). Process syllabus for the language classroom. In C. J. Brumfit (Ed.), General English syllabus design ELT Document, 118, (pp. 47-60). Oxford: Pergamon Press.

Brown, H. D. (2001). Teaching by principles: An interactive approach to language pedagogy (2nd ed.). New York: Addison Wesley Longman.

Croes, M.J. (1990). The efficacy of employing a writing process approach for the instruction of language arts with learning disabled elementary students. Dissertation Abstracts International, 51(12A), 4083. (UMI No.AAI9115193).

Curtis, A. (2001). Hong Kong Student Teachers' Responses to Peer Group Process Writing. Asian Journal of English Language Teaching, II: 129-143.

Crystal, D. (1997). English as a Global Language. Cambridge: Cambridge University Press.

De La Paz, S., \& Graham, S. (2002).Explicitly teaching strategies, skills and knowledge: Writing instruction in middle school classrooms. Journal of Educational Psychology, 94(4), 687-698.

Dean-Rumsey, T. A. (1998). Improving the writing skills of at risk students through the use of writing across the curriculum and writing process instruction. Dissertation Abstracts International, 37(06A), 1598. (UMI NO.AA11395724).

Elbow, P. (1973). Writing without teachers. New York: Oxford University Press.

Elbow, P. (2003). Writing with power. New York: Oxford University Press.

Eldar, D., Paul, L. (1994). Research Within Reach: Oral and Written Communication. St. Louis, MO: CEMREL, Inc., development model. New Directions for Community College, 130, 39-48.

Faigley, L. et al. (1996). Assessing Writing Knowledge and Processes of Composing. Norwood, NJ: Ablex.

Farhady, H., \& Hedayati, H. (2009). Language assessment policy in Iran. Annual Review of Applied Linguistics, 29, $132-141$

Farhady, H., Sajadi Hezaveh, F., \& Hedayati, H. (2010). Reflections on foreign language education in Iran. TESL-EJ, 13 (4).Retrieved January 1, 2012, from http://www.tesl-ej.org.

Goatly, A. (2000). Critical reading and writing. London: English Route.

Goldstein, A., \& Carr, P. G. (1996). Can students benefit from process writing? Washington, DC: Natinal Center for Education Statistics.

Graddol, D. (1997). The Future of English? London: British Council.

Graves, D. (1983). Writing: Teachers and Children at Work. Portsmouth, NH: Heinemann Educational Books.

Harris, E.A. (1992). The relationship of attitudes and writing abilities to computer writing and peers critique of writing. Disserttation Abstract International, 53 (06A), 1828. (UMI No.AAI9224268).

Holec, H. (1981). Autonomy and foreign language learning. Oxford: Pergamon.

Hyland, K. (2002). Genre-based pedagogies: A social response to process. Journal of Second Language Writing, 12, 1729.

Jones, D. (2007). The fundamentals of critical reading and effective writing. Retrieved August 27, 2010, from http://www.criticalreading.com/criticalreadingthinkingtoc.htm.

Jones, E. A., Hoffman, S., Moore, L. M., Ratcliff, G., Tibbetts, S., \& Click, B. A. L. (1995). National assessment of college learning: Identifying college graduates' essential skills in writing, speech and listening, and critical thinking. Washington, DC: US Department of Education.

Littlewood, W. (1996). Autonomy: an anatomy and a framework. System, 24:4, 427-435.

Murray, D. (1972). Teach writing as a process not product. In R. Graves (ED.), Rhetoric and Composition; A sourcebook for teachers and writers (pp.89-92). Upper Montclair, NJ: Boynton/Cook.

Murray, D. (1985). A writer teaches writing ( $2^{\text {nd }}$ Ed.). Boston: Houghton Mifflin

Nunan, D. (1995). ATLAS Learning-centered Communication. Boston: Heinle \& Heinle/International Thompson Publishing.

O’ Brien, T. (2004). Writing in a foreign language: Teaching and learning. Language Teaching 37: 1-28. 
Parson, G. (1985). The Writing Process and the Microcomputer. Two Revolutions in the Teaching of Writing. A Manual for Secondary Teachers. Juneau, AK: Alaska State Department of Education.

Paul, R. \& Elder, L. (2003). The Miniature Guide to Critical Thinking Concepts and Tools. Dillion Beach CA: The Foundation for Critical Thinking.

Renner, C. E. (1996). Enrich learners' language production through content-based instruction. Paper presented at a National Conference on Lingua e Nuova Didattica, Modena, Italy. (ERIC Document Reproduction Service No. ED 411 694).

Riazi, A. (2005). The four language stages in the history of Iran. In A.M.Y. Lin and P.W. Martin (ed.). Decolonization, globalization: Language-in-education policy and practice, (98-114). Clevedon, UK: Multilingual Matters.

Richards J. C. \& Renandya, W. A. (2002). Methodology in Language Teaching: An Anthology of Current Practice, Cambridge: Cambridge University Press.

Smith, C. B. (2000). Writing instruction: Changing views over the years. ERIC Digest D155.

Sommers, N. (1982). Revision strategies of student writers and experienced adult writers. College Composition and Communication, 31, 378-88.

Steele, V. (2004). Product and process writing. Retrieved on 5th Sept. 2010 from http://www.englishonline.org.cn/en/teachers/workshops/teaching-writing/teaching-tips/product-process.

Tribble, C. (1996). Writing. Oxford: Oxford University Press.

University College. (2006). Critical thinking as a core academic skill: A review of the literature. Adelphi, MD: University of Maryland University College.

White, L. \& Marika, R., Ngurruwutthun, D. (1992). Always together, Yakagäna: Participatory

Research at Yirrkala as part of the development of Yolngueducation. Convergence, 25(1), 23-39.

Yeung, Y. (2008). The Impact of the Process approach to the Teaching and Learning of Writing on the Development of Learner Autonomy in Writing in the Secondary School Classroom in Hong Kong. Unpublished doctoral dissertation. Hong Kong: University of Hong Kong. 